\title{
The Comparison of Standard and Salvage Chemotherapy Regimens Regarding to CD34(+) Peripheric Stem Cell Harvesting Success
}

\author{
Ozlem S. BALCIK ${ }^{1}$, Cafer AKSOY ${ }^{2}$, Derya AKDENIZ ${ }^{3}$, Cigdem AKKAYA², \\ Birol GUVENC ${ }^{4}$, Suleyman DINÇER ${ }^{2,5}$ \\ ${ }^{1}$ Turgut Ozal University Faculty of Medicine, Department of Hematology, Ankara \\ ${ }^{2}$ Bayındır Hospital Bone Marrow Transplantation Unit, Ankara \\ ${ }^{3}$ Turgut Ozal University Faculty of Medicine, Department of Internal Medicine, Ankara, \\ ${ }^{4}$ Cukurova University Faculty of Medicine, Department of Hematology, Adana \\ ${ }^{5}$ Yeditepe University Faculty of Medicine, Department of Hematology, Istanbul, TURKEY
}

\begin{abstract}
Although regimens of harvesting peripheric stem cell vary from one center to another, the most common ones are chemotherapy plus growth factor or growth factor alone. We aimed to determine which variables of harvesting peripheral stem cells are effective on the number of harvested CD34+ cells and successfull mobilisation defined as "the collection of $>2.0 \times 106$ CD34+ cells $/ \mathrm{kg}$ b.w. with a maximum of three leukaphereres". From August 2008 to January 2011, the documents of 56 patients included in the autologous peripheral stem cell harvesting program were retrieved retrospectively. Regarding harvesting regimens, 28 patients (50.0\%) were administered filgrastim $10 \mu \mathrm{g} / \mathrm{kg} /$ day (filgrastim group), 18 patients (32.1\%) were administered a standard regime with ifosphami$\mathrm{de}+$ etoposide + epirubicin + filgrastim $5 \mu \mathrm{g} / \mathrm{kg} /$ day or cyclophosphamide + etoposide + filgrastim $5 \mu \mathrm{g} / \mathrm{kg} / \mathrm{day}$ (standard group), and 10 patients (17.9\%) were administered a salvage regime + filgrastim $5 \mu \mathrm{g} / \mathrm{kg} /$ day (salvage group). Rituximab was added if the disease was $\mathrm{CD} 20$ positive. The median number of CD34+ cells and the number of inadequate collection did not differ between these 3 groups. Transplantation before mobilization was found to have a negative effect on the harvesting success. The transplantated patients had a lower number of harvested CD34+ cells than the patients without transplantation history. But no clear relationship was seen between harvest success and the diagnosis of the patients, pretransplant response, radiotherapy history before mobilization, or mobilization with a standard regimen. Finally, the number of standard CT cycles before mobilization were found to have a borderline negative effect on the harvested CD34+ cells.
\end{abstract}

Keywords: G-CSF, Salvage chemotherapy, CD34+ cells, Harvesting, Autologous transplantation 
Periferik kök hücre toplama rejimleri merkezden merkeze değişmekle birlikte, en sık tercih edilen kemoterapi ile birlikte büyüme faktörü (G-CSF, GM-CSF) veya yalnızca büyüme faktörü uygulanmasıdır. CD34+ kök hücreler standart toplama rejimleri ardından toplanabileceği gibi salvaj kemoterapileri takiben de toplanabilir. Çalışmamızda standart toplama ve salvaj kemoterapi protokollerinin mobilizasyon başarısı açısından karşılaştıııması amaçlanmışıı. Ağustos 2008- Ocak 2011 arasında otolog periferik kök hücre toplama programına dahil edilen 56 hastanın dosyaları retrospektif olarak tarandı. Yirmi sekiz hastaya (50.0\%) filgrastim $10 \mu \mathrm{g} / \mathrm{kg} / \mathrm{gün}$ (1. grupfilgrastim), 18 hastaya (32.1\%) ifosfamid + etoposid + epirubisin + filgrastim $5 \mathrm{~g} / \mathrm{kg} / \mathrm{gün}$ veya siklofosfamid + etoposid + 5 $\mu \mathrm{g} / \mathrm{kg} / \mathrm{gün}$ 'den oluşan bir standart toplama protokolü (2. grup-standart), 10 hastaya (17.9\%) ise bir salvaj rejim + filgrastim 5 $\mu \mathrm{g} / \mathrm{kg} / \mathrm{gün}$ (3. grup-salvaj) uygulanmıştı. Mobilize edilen median CD34+ hücre ve yetersiz toplama sayıları her üç grupta da benzerdi. Mobilizasyon öncesi nakil öyküsünün olması, toplama işleminin başarısı üzerinde negatif bir etkiye sahip bulundu. Nakil öyküsü olanlarda, olmayanlara göre toplanan CD34+ hücre sayısı daha düşüktü. Bununla birlikte hastaların tanıları, nakil öncesi hastalık durumları, mobilizasyon öncesi radyoterapi öyküsü gibi parametrelerin toplama işleminin başarısı üzerine etkisi saptanmadı. Çalışmamızda CD34+ hücre mobilizasyonu açısından standart toplama ve salvaj kemoterapi protokolleri arasında fark saptanmamıştır. Standart toplama ve salvaj kemoterapi protokollerinin mobilizasyon başarısı açısından karşılaştıııması için çok sayıda olgu içeren prospektif ve randomize klinik çalışmalara intiyaç vardır.

Anahtar Kelimeler: G-CSF, kurtarma kemoterapisi, CD34+ hücre, Hematopoetik kök hücre toplama, Otolog nakil

\section{INTRODUCTION}

Mobilization of progenitor cells into the blood is mandatory before harvesting via leukapheresis. This was achieved by administration of myelosuppressive drugs (cytotoxic mobilization), resulting in considerably increased peripheric blood progenitor cell (PBPC) levels during the recovery phase. ${ }^{1}$ As recombinant human haematopoietic growth factors have become available for clinical application, it has been demonstrated that the PBPC pool can effectively be expanded by granulocyte colony-stimulating factor (G-CSF) and granulocyte-macrophage colony-stimulating factor (GM-CSF) ${ }^{2-4} \mathrm{Com}-$ bination with cytotoxic therapy may further improve the yield of CSF-induced PBPC mobilization. ${ }^{3,5}$

Previous studies in patients with lymphoma and leukaemia, using different mobilization protocols and varying definitions of 'poor mobilization', showed that $10-25 \%$ of all patients fail to mobilise a sufficient number of PBSC. ${ }^{6-8}$ Poor mobilization of PBSC has been associated with a number of mainly disease and treatment-related factors such as previous chemotherapy (CT) (ie large number of CT cycles for premobilization), previous large-field radiotherapy, prior exposure to certain kinds of 'stem-cell toxic' CT (ie carmustine, melphalan, fludarabine), short interval from last CT to mobilization, tumour infiltration of bone marrow and high age. ${ }^{69-13}$
In this study, we aimed to compare the efficacy of different premobilization protocols on harvesting the number of CD34+ cells, including only G-CSF, G-CSF plus a standard CT regimen or G-CSF plus a salvage chemotherapy (SC).

\section{PATIIIENTS AND METHODS}

\section{Patient Selection and Eligibility Criteria}

We conducted a retrospective review of the 56 patients included in the autologous peripheral stem cell harvesting program in the Bayındır Hospital Bone Marrow Transplantation Unit From August 2008 to January 2011. Inclusion criteria were as follows: adequate organ funcion as defined by serum transaminase levels $<3 \mathrm{x}$ upper limit of normal reference value; total bilirubin $<2 \mathrm{mg} / \mathrm{dL}$; creatinine clearance $\geq 60 \mathrm{~mL} / \mathrm{min}$; left ventricular ejection fraction greater than $45 \%$, Eastern Cooperative Oncology Group (ECOG) performance status $>2$, white blood cell count $>3500 / \mathrm{ml}$, hemoglobin level $>8$ $\mathrm{g} / \mathrm{dl}$, platelets $>100000 / \mathrm{ml}$. Patients were required to test negative for antibodies against HIV and to be free of active infection. There was no age restriction. Patients provided informed consent prior to inclusion. The study was approved by the respective local Ethics Committee. 


\section{Study Groups \\ Filgrastim Group}

Twenty-eight patients (50\%) were mobilised with filgrastim (nonglycosylated G-CSF; Neupogen $®$ ) at a dose of $10 \mu \mathrm{g} / \mathrm{kg} /$ day s.c. once daily. Filgrastim was commenced on day +2 , continued until harvesting was completed.

\section{Standard Group}

Eighteen patients $(32,1 \%)$ were mobilised with a standard chemoterapy regimen including cyclophosphamide (Cy) + etoposide or IEV (ifosphamide, etoposide, epirubicin) followed by filgrastim at a dose of $5 \mu \mathrm{g} / \mathrm{kg} /$ day s.c. once daily. Cy $4 \mathrm{~g} / \mathrm{m}^{2}$ with an equal dose of uromethexane intravenously (i.v.) was given on day 1 , etoposide $200 \mathrm{mg} / \mathrm{m}^{2}$ on days 1-3. The IEV regimen was administered consisting of ifosphamide $2.5 \mathrm{~g} / \mathrm{m}^{2} / \mathrm{d}$ i.v. continuous infusion over $24 \mathrm{~h}$ on days $1-3$, etoposide $100 \mathrm{mg} / \mathrm{m}^{2} / \mathrm{d}$ i.v. over $2 \mathrm{~h}$ on days $1-3$ and epirubicin $100 \mathrm{mg} / \mathrm{m}^{2}$ i.v. bolus on day 1 . Uromethexane was administered at a dose of $2.5 \mathrm{~g} / \mathrm{m}^{2}$ i.v. prior to the first dose of ifosphamide, $2.5 \mathrm{~g} / \mathrm{m}^{2} / \mathrm{d}$ i.v. continuous infusion on days 1-3 and over $12 \mathrm{~h}$ upon completion of the ifosphamide infusion. In addition, prophylactic phenytoin $300 \mathrm{mg} / \mathrm{d}$ was administered from D-1 to D+8. GCSF was commenced 24 hours after the completion of the $\mathrm{CT}$ and continued until harvesting was completed for both protocols.

\section{Salvage Group}

Ten patients $(17.9 \%)$ received a salvage chemotherapy including high-dose ARA-C (cytosine arabinoside), Hiper-CVAD (cyclophosphamide, doxorubicin, vincristine, dexamethasone), DHAP (cytosine arabinoside, cisplatin, dexamethasone), R (rituximab)-DHAP, BEAM (carmustine, etoposide, cytosine arabinoside, melphalan), R-BEAM, R-ICE (rituximab, ifosfamide, carboplatin, etoposide) followed by filgrastim using the same dose and schedule (see above) as for standard group (only the patients who administered ICE or R-ICE regimens, G-CSF was administered at $5 \mu \mathrm{g} / \mathrm{kg}$ on days 5-12).

\section{Salvage Chemotherapy Regimens}

The high-dose ARA-C regimen included cytosine arabinoside $3 \mathrm{~g} / \mathrm{m}^{2}$ twice daily on days $1-3$. The Hyper-CVAD regimen consisted of $\mathrm{Cy}$ at a dose of $300 \mathrm{mg} / \mathrm{m}^{2}$ per dose given i.v. over 3 hours every 12 hours for 6 doses on days 2-4. Uromethexane was started 1 hour before the start of $\mathrm{Cy}$, at a dose of $600 \mathrm{mg} / \mathrm{m}^{2}$ i.v. and was given over 24 hours daily on days 2-4, with the infusion completed 12 hours after administration of the last dose of Cy. Twelve hours after the last dose of $\mathrm{Cy}$, doxorubicin at a dose of $26.3 \mathrm{mg} / \mathrm{m}^{2}$ was given by continuous i.v. infusion over 24 hours daily on days 5-7. Vincristine at a dose of $1.4 \mathrm{mg} / \mathrm{m}^{2}$ (maximum absolute dose, 2 $\mathrm{mg}$ ) was given by i.v. infusion 12 hours after the last dose of $\mathrm{Cy}$ and was repeated on day 12 of the cycle. Dexamethasone at a $40 \mathrm{mg}$ absolute dose was given orally or i.v. on days 2-5 and 12-15 of the cycle. The DHAP regimen was administered as follows: cisplatin $100 \mathrm{mg} / \mathrm{m}^{2}$ was infused over 4 hours on day 1 , cytosine arabinoside $2 \mathrm{~g} / \mathrm{m}^{2}$ in 3 hours i.v. twice a day on day 2 , and dexamethasone $40 \mathrm{mg}$ given orally or i.v. on days 1-4. The ICE regimen was administered as follows: etoposide $100 \mathrm{mg} / \mathrm{m}^{2}$ i.v. on days 1-3; carboplatin $300 \mathrm{mg} / \mathrm{m}^{2}$ (to a maximum dose of $800 \mathrm{mg}$ ) i.v. on day 2, ifosfamide 1700 $\mathrm{mg} / \mathrm{m}^{2}$ with an equal dose of uromethexane i.v. on days $1-3$, and G-CSF administered at $5 \mu \mathrm{g} / \mathrm{kg}$ on days 5-12. The BEAM regimen included carmustine (BCNU) $60 \mathrm{mg} / \mathrm{m}^{2}$ on day 2, etoposide 120 $\mathrm{mg} / \mathrm{m}^{2}$ on days $4-7$, cytosine arabinoside $200 \mathrm{mg} / \mathrm{m}^{2}$ q12h on days $4-7$, and melphalan $30 \mathrm{mg} / \mathrm{m}^{2}$ on day 3. Rituximab $375 \mathrm{mg} / \mathrm{m}^{2}$ was added if the disease was CD20 positive. Total white blood count (WBC), mononuclear cells, and CD34 + cells were analysed daily during haematopoietic recovery.

\section{Leukapheresis}

Leukapheresis was performed with a continuous flow blood cell separator (Fresenius) using a double-lumen central-venous catheter. Ten to 12 (median 11) liters of blood were processed daily at a flow rate of $30-60 \mathrm{~mL} \mathrm{min-'.} \mathrm{The} \mathrm{harvest} \mathrm{products} \mathrm{were}$ freezed and cryoperserved in 10\% DMSO at -196 C using standard techniques. All patients tolerated the mobilization and cell separation procedures well. 


\begin{tabular}{|c|c|c|c|c|}
\hline Groups & Filgrastim & Standard & Salvage & $\mathbf{p}$ \\
\hline Number of patients (\%) & 28 & 18 & 10 & 0.157 \\
\hline Women & $10(35.7 \%)$ & $10(55.6 \%)$ & $2(20 \%)$ & \\
\hline Men & $18(64.3 \%)$ & $8(44.4 \%)$ & $8(80 \%)$ & \\
\hline Age & $47.0 \pm 13.8$ & $46.4 \pm 12.0$ & $34.5 \pm 16.0$ & 0.043 \\
\hline Total number of aphereses & 37 & 23 & 12 & 0.271 \\
\hline Median number of aphereses (range) & $2(1-4)$ & $2(1-4)$ & $2(1-3)$ & 0.273 \\
\hline Median number of CD34+ cells x106/kg (range) & $5.4(1.2-11.8)$ & $8.3(0.3-41.4)$ & $5.4(0.6-13.7)$ & 0.131 \\
\hline The number of inadequate collection (\%) & $4(10.8 \%)$ & $3(13.0 \%)$ & 4 (33.3\%) & 0.210 \\
\hline
\end{tabular}

\section{Harvest of Stem Cells}

The time of apheresis depended on the CD34 + cell count of the peripheral blood. Post nadir, the WBC was analysed daily to identify regeneration (WBC $\left.>1.0 \times 10^{9} / 1\right)$, after which the number of CD34+ cells in blood was determined daily. Leukapheresis was commenced when the total white count reached $1 \times 10^{9} / 1$ or when levels of CD34 cells reached 30/ml. Leukapheresis and CD34+ cell selection continued until at least $2 \times 10^{6} \mathrm{CD} 34$ enriched cells had been stored. "Successful mobilization" was defined as "the collection of $>2.0 \times 10^{6} \mathrm{CD} 34+$ cells/kg b.w. with a maximum of three leukaphereres".

\section{RESULTS}

\section{Patient characteristics}

The filgrastim, standard and salvage groups included $28(50 \%), 18(32.1 \%)$, and 10 (17.9\%) patients, respectively. Of 56 patients, 22 were female (39.3\%) and the median age was 44.6 years (range: 16-71 years). There was no significant difference between groups in terms of sex (Table 1), but the salvage group was significantly younger than the filgrastim group ( $\mathrm{p}=0.041)$. The distribution of underlying diagnoses in the patients is given in Table 2.

\begin{tabular}{|c|c|c|c|c|}
\hline & Filgrastim (\%) & Standard (\%) & Salvage (\%) & Total (\%) \\
\hline MM (\%) & 11 (39.2\%) & 8 (44.4\%) & $0(0 \%)$ & 19 (33.9\%) \\
\hline AML and ALL (\%) & 1 (3.5\%) & 2 (11.1\%) & 4 (40.0\%) & 7 (12.5\%) \\
\hline NHL (\%) & $8(28.5 \%)$ & 6 (33.3\%) & $3(30.0 \%)$ & 17 (30.3\%) \\
\hline HD (\%) & 6 (21.4\%) & 2 (11.1\%) & 3 (30.0\%) & 11 (19.6\%) \\
\hline Others (\%) & $2(7.1 \%)$ & $0(0 \%)$ & $0(0 \%)$ & 2 (3.5\%) \\
\hline Total (\%) & 28 (100\%) & 18 (100\%) & 10 (100\%) & 56 (100\%) \\
\hline
\end{tabular}




\begin{tabular}{|c|c|c|}
\hline $\begin{array}{l}\text { The number of harvested } \\
\text { CD34+ cells } \times 10^{6} / \mathrm{kg} \text { (range) }\end{array}$ & & p \\
\hline Pretransplant response & & 0.121 \\
\hline $\mathrm{CR}$ & $6.4(1.6-41.4)$ & \\
\hline PR & $4.3(0.3-39.7)$ & \\
\hline Radiotherapy before mobilization & & 0.887 \\
\hline Yes & $6.5(0.3-27.8)$ & \\
\hline No & $6.2(0.6-41.4)$ & \\
\hline Transplantation before mobilizatior & & 0.017 \\
\hline Yes & $4.1(0.6-6.8)$ & \\
\hline No & $6.4(0.3-41.4)$ & \\
\hline Diagnosis & 0.304 & \\
\hline $\mathrm{MM}$ & $7.2(0.8-39.7)$ & \\
\hline$A M L+A L L$ & $6.5(2.5-11.6)$ & \\
\hline $\mathrm{NHL}$ & $5.6(0.6-41.4)$ & \\
\hline $\mathrm{HD}$ & $4.8(0.3-11.1)$ & \\
\hline Mobilisation with standard regimer & & 0.740 \\
\hline IEV & $8.8(0.8-39.7)$ & \\
\hline$C Y C+E P$ & $7.9(0.3-41.4)$ & \\
\hline \multicolumn{3}{|c|}{$\begin{array}{l}\text { Abbreviations: CR: Complete remission; PR: Partial remission; } \\
\text { MM: Multiple myeloma; AML: Acute myelogeneus leukemia; } \\
\text { ALL: Acute lymphoblastic leukemia; NHL: Non-Hodgkin lym- } \\
\text { phoma; HD: Hodgkin disease; IEV: Iphosphamide, etoposide, } \\
\text { epirubicin; CYC: Cyclophosphamide; EP: Etoposide }\end{array}$} \\
\hline
\end{tabular}

\section{Ia. Filgrastim Group}

The median number of leukaphereses was 2 per patient (range: 1-4). The median number of harvested peripheral CD34+ cells was $5.4 \times 10^{6} / \mathrm{kg}$ (range: 1.2-11.8 x $10^{6} \mathrm{CD} 34+$ cells $\left./ \mathrm{kg}\right) .4$ aphereses $(10.8 \%)$ were insufficient (Table 1).

\section{Ib. Standard group}

Ten patients (\%55.5) received $\mathrm{Cy}+$ etoposide, and 8 (\%44.5) patients received IEV. The median number of leukaphereses was 2 per patient (range: 1-4). The median number of harvested peripheral CD34+ cells was $8.3 \times 10^{6} / \mathrm{kg}$ (range: $0.3-41.4 \times 10^{6} \mathrm{CD} 34+$ cells $/ \mathrm{kg}$ ). 3 aphereses (13.0\%) were insufficient (Table 1).

\section{Ic. Salvage group}

The median number of leukaphereses was 2 per patient (range: 1-3). The median number of harvested peripheral CD34+ cells was $5.4 \times 10^{6} / \mathrm{kg}$ (range: 0.6-13.7 x $10^{6} \mathrm{CD} 34+$ cells $\left./ \mathrm{kg}\right) .4$ apheresis (33.3\%) were insufficient (Table 1).

The total and median number of aphereses, the median number of CD34+ cells and also the number of inadequate collection were not significantly different between study groups (Table 1).

\section{The effects of disease and treatment related factors on harvesting process}

\section{IIa. Disease status before harvesting procedure}

The median number of harvested peripheral CD34+ cells was not statistically different in patients with complete or partial remission (Table 3).

\section{IIb. Effect of previous radiotherapy}

The median number of harvested peripheral CD34+ cells was not statistically different in patients treated with radiotherapy or untreated previously (Table 3). Sixty-one $(84.7 \%)$ of the 72 aphereses was accepted as successfull $\left(>2.0 \times 10^{6} \mathrm{CD} 34+\right.$ cells $/ \mathrm{kg}$ b.w.). Five ( $8.2 \%$ ) of the sufficient aphereses, and $2(18.2 \%)$ of the insufficient aphereses had a previous history of radiotherapy. But the difference was not statistically significant (Table 4).

\section{IIc. Hematopoietic stem cell transplantation be- fore harvesting}

The median number of harvested peripheral CD34+ cells was $4.1 \times 10^{6} / \mathrm{kg}$ (range: 0.6-6.8 x $10^{6} \mathrm{CD} 34+$ cells $/ \mathrm{kg}$ ) and $6.4 \times 10^{6} / \mathrm{kg}$ (range: 0.3-41.4 x $10^{6}$ $\mathrm{CD} 34+$ cells $/ \mathrm{kg}$ ) in patients received hematopoietic stem cell transplantation or not. The median number of CD34+ cells was significantly higher in patients without transplantation (Table 3). Of the 61 sufficient aphereses, $5(2.7 \%)$ of them had a previous transplantation history, while this number was $3(4.1 \%)$ in insufficient aphereses. But the difference was not statistically significant (Table 4).

\section{IId. Effect of diagnosis}

The median number of harvested peripheral CD34+ cells of the patients was not statistically different according to their diagnosis (Table 3). 


\begin{tabular}{|c|c|c|c|}
\hline & Inadequate collection & Adequate collection & $\mathbf{p}$ \\
\hline Groups & & & 0.210 \\
\hline Filgrastim & $4(10.8 \%)$ & 33 (89.2\%) & \\
\hline Standard & $3(13.0 \%)$ & 20 (87.0\%) & \\
\hline Salvage & 4 (33.3\%) & $8(66.7 \%)$ & \\
\hline HSCT before mobilization & & & 0.098 \\
\hline Yes & $3(27.3 \%)$ & $5(8$ & \\
\hline No & 8 (72.7\%) & 56 (91.8\%) & \\
\hline RT before mobilization & & & 0.289 \\
\hline Yes & $2(18.2 \%)$ & $5(8.2 \%)$ & \\
\hline No & $9(81.8 \%)$ & $56(91.8 \%)$ & \\
\hline
\end{tabular}

\section{IIe. Effect of standard regimens $(\mathrm{Cyc}+$ etoposi- de or IEV)}

The median number of harvested peripheral CD34+ cells of the patients was not statistically different in patients received Cyc + etoposide or IEV (Table 3).

\section{IIf. The effect of age and number of chemothe- rapy cycles}

Age, total number of CT cycles and SC cycles were not found to be related with the number of harvested CD34+ cells. However, a statisticaly borderline difference $(p=0.048)$ between the number of harvested CD34+ cells and the number of standard CT cycles were found (Table 5).

\section{Statistical Analysis}

Data analysis was performed by using SPSS for Windows, version 11.5 (SPSS Inc., Chicago, IL, United States). Whether the distributions of continuous variables were normally or not was determined by using Shapiro Wilk test. Continuous variables were shown as mean \pm standard deviation or median (minimum-maximum), where applicable. The mean ages were compared by using One-Way ANOVA. While the median values between two groups were analyzed by Mann Whitney U test, otherwise, Kruskal Wallis test was used when the number of independent groups was more than two. Nominal data were analyzed by Pearson's Chi-square or Fisher's exact test, where appropriate. Degrees of associations between continuous variables were evaluated by Spearman's correlation test. A p value less than 0.05 was considered as statistically significant.

\section{DISCUSSION}

In this retrospective analysis, 56 patients and 72 aphereses with various hematologic malignancies were evaluated. The following significant results emerged from this study. The patients in the salvage group were significantly younger than the patients in the filgrastim group. The use of only filgrastim, standard CT plus filgrastim or SC plus filgrastim resulted in the successful collection of adequate numbers of PBSC, in 61 of 72 harvesting procedures $(91.6 \%)$ by a median of 2 apheresis. Interestingly, the median number of CD34+ cells and the number of inadequate collection did not differ between 3 procedures. On the other hand, transplantation before mobilization was found to have a negative effect on the harvesting success. The transplantated patients had a lower number of harvested CD34+ cells than the patients without transplantation history. But no clear relationship was seen between harvest success and the diagnosis of the patients, pretransplant response, radiotherapy history 


\begin{tabular}{|lll|}
\hline $\begin{array}{l}\text { Table 5. The correlation and significance between the harvested CD34+ cells and age, total number of CT cycles, the number of } \\
\text { standard cycles and the number of SC cycles before mobilisation }\end{array}$ & Correlation Coefficient & p value \\
\hline & -0.096 & 0.423 \\
\hline Age & -0.174 & 0.144 \\
Total number of CT cycles before mobilisation & -0.234 & 0.048 \\
Number of standard CT cycles before mobilisation & -0.126 & 0.293 \\
Number of SC cycles before mobilisation & & \\
\hline Abbreviations: CT: chemotherapy; SC: salvage chemotherapy & & \\
\end{tabular}

before mobilization, or mobilization with a standard regimen $(\mathrm{Cyc}+$ Etoposide or IEV). Finally, the number of standard CT cycles before mobilization were found to have a borderline negative effect on the harvested CD34+ cells.

There is a good correlation between the number of CD34+ cells infused and haematopoietic recovery $^{14}$, and a threshold number of $>2 \times 10^{6} \mathrm{CD} 34+$ cells $/ \mathrm{kg}$ b.w. has been found to ensure prompt autologous engraftment. ${ }^{15}$ PBPC collection should start immediately after the WBC has exceeded $10.0 \mathrm{~nL}$ 1 and might be terminated as soon as more than $2 \mathrm{x}$ $10^{6} \mathrm{CD} 34+$ cells are harvested.$^{16}$ The optimal scheduling of G-CSF, as combined with CT for mobilization of PBSC, is not known and may depend on the CT regimen used. ${ }^{10}$ In most protocols, G-CSF is started 1-2 days after CT and administered once daily until completion of leukapheresis. However, results from two nonrandomised studies of PBSC mobilization (not including AML patients) suggest that the addition of G-CSF may be delayed until 5-8 days after chemotherapy. ${ }^{17,18}$ In the present study, regular measurements of CD34+ cells in blood were performed during recovery (WBC > 1 x 10\%/l) after chemotherapy. G-CSF was commenced at a dose of $10 \mu \mathrm{g} / \mathrm{kg} /$ day in filgrastim group and $5 \mu \mathrm{g} / \mathrm{kg} /$ day in standard and salvage groups, on day +2 , continued until harvesting was completed.

The mobilization of PBSC has been shown to be more effective in patients at diagnosis as compared with patients with refractory or relapsed lymphoma. ${ }^{19}$ However, SC regimens have also shown to be effective in mobilisizing adequate number of PBSC. The use of DHAP followed by G-CSF 10 $\mu \mathrm{g} / \mathrm{kg}$ resulted in the successful collection of adequate numbers of PBSC in $97.1 \%$ of patients with a median harvest of CD34+ cells of $13 \times 10^{6} / \mathrm{kg}$. More than $2.0 \times 10^{6} \mathrm{CD} 34+$ cells $/ \mathrm{kg}$ were achieved in $63 \%$ patients after 1 apheresis, the maximum number of aphereses for all patients was 3. It was found that the optimal time of PBSC harvest was at days 13-16 after initiating the mobilization regimen..$^{20}$ In a previous study using DHAP as salvage treatment in 79 patients with non-Hodgkin's lymphoma and $\mathrm{HD}, 85.5 \%$ of patients achieved at least $>=2 \mathrm{x}$ $10^{6} / \mathrm{kg} \mathrm{CD} 34+$ cells and only $10 \%$ of patients with HD failed the mobilization. ${ }^{21}$

Patients who mobilize PBPC poorly are also likely to have poor quality marrow, and may also have a greater degree of marrow stromal damage. The number of cycles and duration of previous chemotherapy, the interval between previous chemotherapy and mobilization, and exposure to stem cell toxic drugs such as melphalan and nitrosoureas have all been correlated with PBPC yield. ${ }^{22}$ Similarly Clark et al. suggested that previously treated patients with melphalan or carmustine were associated with a significantly lower yield of CD34+ cells. In contrast, no relationship was seen between the time from previous chemoradiotherapy and harvest outcome. ${ }^{23}$ In the present study, potentially stem cell toxic agents were not preferred for therapy.

Our analysis has several limitations. First, it is a retrospective analysis. Second, the small sample size limits its statistical power. Despite its limitations, our study gives an idea of some disease and treatment-related factors on the efficacy of harvesting adequate numbers of PBSC in patients with various hematological malignancies. 


\section{CONCLUSION}

The median number of CD34+ cells and the number of inadequate collection were similar between the filgrastim, standard and salvage groups. Transplantation before mobilization was found to have a negative effect on the harvesting success. The transplantated patients had a lower number of harvested CD34+ cells than the patients without transplantation history. But no clear relationship was seen between harvest success and the diagnosis of the patients, pretransplant response, radiotherapy history before mobilization, or mobilization with a standard regimen. The number of standard CT cycles before mobilization were found to have a borderline negative effect on the harvested CD34+ cells. Further studies are needed to examine the optimal clinical approach in patients who mobilise PBPC poorly following conventional mobilising schedules.

\section{REFERENCES}

1. Richman CM, Weiner RS, Yankee RA. Increase in circulating stem cells following chemotherapy in man. Blood 47: 1031-1039, 1976.

2. Dührsen U, Villeval JL, Boyd J, et al. Effects of recombinant human granulocyte colony-stimulating factor on hematopoietic progenitor cells in cancer patients. Blood 72: 2074-2081, 1988.

3. Aksu S, Goker H, Haznedaroglu IC, et al. Erişkinlerde Hematopoietik Kök Hücre Transplantasyonu: Hacettepe Hematoloji Deneyimi: 2001-2004. UHOD: 4, 181183, 2005.

4. DeLuca E, Sheridan WP, Watson D, et al. Prior chemotherapy does not prevent effective mobilization by G-CSF of peripheral blood progenitor cells. Br J Cancer 66: 893-899, 1992.

5. Gianni AM, Siena S, Bregni M, et al. Granulocyte-macrophage colony-stimulating factor to harvest circulating haemopoietic stem cells for autotransplantation. The Lancet 2: 580-585, 1989.

6. Schlenk RF, Dohner H, Pforsich M, et al. Successful collection of peripheral blood progenitor cells in patients with acute myeloid leukaemia following early consolidation therapy with granulocyte colony-stimulating factor-supported high dose cytarabine and mitoxantrone. Br J Haematol 99: 386-393, 1997.

7. Castagnola C, Alessandrino EP, Lunghi M, et al. Consolidation treatment with autologous peripheral blood progenitor cell transplantation in acute myeloid leukemia: a single center experience. Ann Hematol 80: $267-$ 271, 2001.
8. Russell NH, McQuaker G, Stainer $\mathrm{C}$, et al. Stem cell mobilization in lymphoproliferative diseases. Bone Marrow Transplant 22: 935-940, 1998.

9. Visani G, Lemoli RM, Tosi P, et al. Fludarabine-containing regimens severely impair peripheral blood stem cells mobilization and collection in acute myeloid leukaemia patients. Br J Haematol 105: 775-779, 1999.

10. Demirer T, Bensinger WI, Buckner CD. Peripheral blood stem cell mobilization for high-dose chemotherapy. J Hematother 8: 103-113, 1999.

11. Reiffers J. Peripheral blood stem cell transplantation in acute myeloid leukemia: the experience of the Bordeaux Group. Stem Cells 13: 19-22, 1995.

12. Ketterer N, Salles G, Moullet I, et al. Factors associated with successful mobilization of peripheral blood progenitor cells in 200 patients with lymphoid malignancies. Br J Haematol 103: 235-242, 1998.

13. Carral A, de la Rubia J, Martin G, et al. Factors influencing the collection of peripheral blood stem cells in patients with acute myeloblastic leukemia and non-myeloid malignancies. Leuk Res 27: 5-12, 2003.

14. Weaver $\mathrm{CH}$, Hazelton $\mathrm{B}$, Birch R, et al. An analysis of engraftment kinetics as a function of the CD34 content of peripheral blood progenitor cell collections in 692 patients after the administration of myeloablative chemotherapy. Blood 86: 3961-3969, 1995.

15. Tricot G, Jagannath $\mathrm{S}$, Vesole $\mathrm{D}$, et al. Peripheral blood stem cell transplants for multiple myeloma: identification of favorable variables for rapid engraftment in 225 patients. Blood 85: 588-596, 1995.

16. Dreger P, Marquardt P, Haferlach T, et al. Effective mobilization of peripheral blood progenitor cells with 'Dexa-BEAM' and G-CSF: timing of harvesting and composition of the leukopheresis product. $\mathrm{Br} \mathrm{J}$ Cancer 68: 950-957, 193.

17. Haynes A, Hunter A, McQuaker G, et al. Engraftment characteristics of peripheral blood stem cells mobilised with cyclophosphamide and the delayed addition of GCSF. Bone Marrow Transplant 16: 359-363, 1995.

18. Benet I, Prosper BF, Marugan I, et al. Mobilization of peripheral blood progenitor cells (PBPC) in patients undergoing chemotherapy followed by autologous peripheral blood stem cell transplant (SCT) for high risk breast cancer (HRBC). Bone Marrow Transplant 23: 1101-1107, 1999.

19. Tarella C, Castellino C, Cherasco C, et al. Peripheral blood progenitor cell mobilization in patients with primary refractory lymphoma or at first relapse: comparison with patients at diagnosis and impact on clinical outcome. Br J Haematol 99: 41-46, 1997.

20. Smardova L, Engert A, Haverkamp H, et al. Successful mobilization of peripheral blood stem cells with the DHAP regimen (dexamethasone, cytarabine, cisplatinum) plus granulocyte colony-stimulating factor in patients with relapsed Hodgkin's disease. Leuk Lymphoma 46: 1017-1022, 2005. 
21. Olivieri A, Brunori M, Capelli D, et al. Salvage therapy with an outpatient DHAP schedule followed by PBSC transplantation in 79 lymphoma patients: an intention to mobilize and transplant analysis. Eur $\mathrm{J}$ Haematol 72 : 10-17, 2004.

22. To LB, Haylock DN, Simmons PJ, et al. The biology and clinical uses of blood stem cells. Blood 89: 22332258, 1997.

23. Clark RE, Brammer CG. Previous treatment predicts the efficiency of blood progenitor cell mobilization: validation of a chemotherapy scoring system. Bone Marrow Transplant 22: 859-863, 1998.

\section{Correspondence}

Dr. Derya AKDENIZ

Alparslan Türkeş Caddesi Mertler Sokak

No: 80 / 4 Emek

ANKARA / TURKEY

Tel: (+90.312) $2035555 / 5821$

e-mail: dr.deryaakdenizz@hotmail.com 